\title{
Improving Research Capacity at Universitas Diponegoro, Indonesia
}

\author{
Yos Johan Utama ${ }^{1, *}$, Ambariyanto Ambariyanto ${ }^{2}$ \\ ${ }^{1,2}$ Gd. Widya Puraya, Kampus Universitas Diponegoro, Jl. Prof. Soedarto S.H., Tembalang, Semarang, Indonesia \\ *corresponding author: ambariyanto@live.undip.ac.id
}

\section{Article Info}

Received:

15 March 2021

Accepted:

25 May 2021

Published:

1 June 2021

DOI:

https://doi.org/10.14710/j

sp.2021.11205

\begin{abstract}
As a higher education institution with a vision to become a research university, programs and activities related to research are Universitas Diponegoro main concern. Research is one of the three main pillars of higher education in Indonesia, apart from education and community service. Besides that, as a state university, its development is also influenced by central government policies. Currently, Undip is a state university with legal status and has wide autonomy. This paper explains research programs, activities and challenges that still need to be addressed in the future. To increase research capacity at Diponegoro University, there are five main programs, namely: 1 . Increasing the capacity of human resources; 2. Improvement of facilities and supporting facilities; 3 . Increasing the availability of research funds, 4 . Collaboration and 5. Creating a conducive environment to research development at universities. Based on the application of the five programs, there has been a substantial increase in a research capacity, especially when viewed from indicators of international scientific publications, and an increase in the number of patents obtained. But there are still many challenges that need to be overcome, including the increase in the citation of published papers and the utilization of patent by industries.
\end{abstract}

\section{Keyword:}

university policy, research improvement, patent, down streaming

\section{Introduction}

Diponegoro University (Undip) is one of the state universities with legal status [1] and has great autonomy compared to other universities in Indonesia, often referred to as a university with legal entity. Undip is located in the city of Semarang, on the north coast of the province of Central Java. Undip students come from all provinces in Indonesia and several other foreign countries. Currently, Undip is one of the universities in Indonesia that has very developed research activities. Besides that, research activities are one of the three main pillars in higher education in Indonesia, in addition to education and community service [2]. 
Academics at Undip come from eleven faculties (including medicine, public health, psychology, marine and fisheries, animal husbandry and agriculture, engineering, science and mathematics, law, economics and business, social and political science, cultural sciences, and two schools (vocational and postgraduate). Undip also has a research institute, an integrated laboratory, a central laboratory (for medical), research groups, a center of excellence on innovation, and technoparks as well as other supporting directorates.

Undip's general policies regarding research activities are strongly influenced by three aspects. First is the policy of the central government in terms of national research development, because the development of state higher education institutions cannot be separated from government policies [3]. Second is Undip's vision as an excellent research university. The third is Undip's status as a university with legal entity as well as to become a world class university, as a sustainable campus [4], and with the main scientific pattern, namely Coastal Region Eco-Development [5].

Undip's various policies are always directed towards this vision. Compared to the condition of Diponegoro University 10 years ago, research-related activities are currently increasing very rapidly. This can be seen from the increase in the number of publications in reputable international journals and in accredited national journals, as well as the increase in the number of patents, books, etc. which are indicators of research performance.

Undip's experience shows that a focused policy is needed if a university is to develop in terms of research. The success of research activities itself is strongly influenced by five factors, namely the capacity of human resources, the availability of main and supporting facilities, the availability of research funds, cooperative activities and a conducive environment. This paper will explain the five factors above and the challenges that must be overcome.

\section{Human Resource Capacity}

Providing one of the main factors for the success of research activities is human resources [6]. Human resources who are passionate about research are needed with a great sense of curiosity about certain topics. It also requires human resources who have the ability and good research experience. However, all academics at Undip are very heterogeneous about the above issues. Policies related to research capacity are needed for academics to improve research activities at Undip.

One of the programs is to provide scholarships for lecturers for doctoral programs. Undip hopes that in the next three years $90 \%$ of all lecturers have doctoral degrees. Through the doctoral program, the research abilities of these lecturers will increase, because they gain experience in completing their dissertations and publications. Another program is through training or workshops, both internal (conducted by Undip) and external (conducted by other institutions). The types of training are very diverse, including research methodology, introduction to the latest research equipment, laboratory accreditation, etc. Through this training, it is hoped that the ability of academics will increase.

Another program is certification as a recognition of certain expertise [7]. For certain fields such as engineering, medicine and public health, science, often requires special skills that require certification. Undip provides funds for academics to take part in the program. Undip also provides opportunities for academics to attend seminars and conferences both nationally and internationally to provide their experiences in presenting research results. Attending seminars or conferences allows them to learn from the experiences of other researchers, including new methods. Every year almost all faculties/schools hold seminars 
or conferences at the national or international level. For organizing this activity, the university provides funding, especially for indexation of proceedings as well as costs for cooperation with journals that will publish articles from seminars/conferences.

\section{Facility Availability}

ATU Both the main and supporting facilities play a very important role in improving research performance [8]. Having very good human resources, but no facilities, then research activities cannot be carried out optimally. Undip has a policy to continuously improve its research facilities by providing a budget every year. Laboratory equipment at Undip is divided into two, namely equipment for educational processes and laboratory equipment for research activities. Each faculty or school has a laboratory on a smaller scale and is primarily for education, although there is also a variety of equipment for research. At the university level, there is an integrated laboratory where various existing equipment can be used by academics or students, including serving sample analysis from outside Undip, as well as the central laboratory for the health and medical.

Every year all faculties or schools, integrated and central laboratories submit a proposal of the required equipment. At the university level, all these proposals will be evaluated, and the purchase of equipment will depend on the funding available. Undip's management commitment is to provide the main and supporting facilities to improve research performance.

\section{Research Funding}

The availability of research funds also greatly affects research performance in universities [9]. Therefore, Undip has the policy to provide research funding for all lecturers in two versions, namely non-competitive with a small amount of funds and competitive with a varying amount of funds from moderate to large funds. Research funding also available for students with competitive based. For students who gets scholarships from Undip including overseas students, research funding also available as part of the scholarship scheme. Through this policy, it is hoped that all lecturers can carry out research according to their abilities and targets.

Research funds can also be obtained from the government which is competitive at the national level. These funds come from the Ministry of Research and Technology, as well as from the Ministry of Finance through the Education Fund Management Institute (LPDP) [10]. The amount of research funding from this ministry is generally quite large, especially from the LPDP Usually the output expected from the funds from these ministries is in the form of publications in international journals, or books, applicable technology, or patents. Other ministries also often provide research funding, but the nature of appointments or assignments is especially related to certain cases (for example Covid-19) through collaboration between Undip and the ministry.

The regional government of Central Java province also often provides research funding for academics in the province, which is competitive with relatively a large amount of funding. Other sources of research funding come from industry through cooperation mechanisms with specific topics needed by the industry. Collaborative research with industry, especially to produce certain products that can be commercialized [11]. Another source of funds that could be very large is foreign research funds. Some researchers get research funding from abroad either from Europe (for example Erasmus), from America (for example PEER funds) or other countries 


\section{Research Collaboration}

Moving Collaboration is one of the keys to success in research [12,13]. Research collaboration with both domestic and foreign researchers and institutions is very influential in improving research performance at Undip. So far, it has been proven that research based on collaboration has produced good publications in journals and has high citations. Therefore, one of Undip's policies to encourage research activities for academics is through collaboration. Undip continues to facilitate academics and students who wish to carry out research collaborations with other researchers and institutions.

This research collaboration can be carried out with researchers from other universities both within and outside the country. Collaboration can also be carried out with the central government (through the ministry that provides funds or facilities, or researchers from the ministry), as well as with the community and industries [14].

Currently, there are many research collaborations carried out by Undip academics. Research activities are carried out at home and in partner institutions abroad. Some foreign researchers are at Undip (with government permission) because foreign researchers carrying out research activities in Indonesia must get permission from the government.

\section{Conclusive}

A conducive environment greatly affects the success of a program [15]. Experience at Undip shows that a conducive environment greatly affects the improvement of research performance. Although all other factors are available, if it is not supported by an environmental atmosphere that encourages academics to research enthusiastically, then an increase in research performance will not be achieved.

There are several ways that Undip has done to create a conducive atmosphere at the university. First, giving awareness to all stakeholders regarding Undip's vision to become an excellent research university. Understanding the vision is very important, however, not only awareness and understanding are expected, but also every step must lead towards that vision. Secondly, an incentive is prepared for outstanding researchers, for example, academics who have the most publications or patents in a certain year, academics who have publications in the Q1 journal (according to Scopus standards), academics who have the most citations, etc. Thirdly, developed rules and regulations that make it possible and easy for academics and students to carry out research, publications, collaborations, seminars/conferences and so on. Based on these rules and regulations, clear standard operating procedures (SOPs) are prepared, making it easier for academics to carry out research and other related activities. The provision of electronic journals in the library also provides an atmosphere that supports research activities.

\section{Enviroment and SDG Related Research}

As a research university towards a sustainable university, Undip conducts research related to the environment and Sustainable Development Goals (SDGs). Research related to the physical environment is mainly carried out by the Environmental Engineering Study Program, at the Faculty of Engineering, also the Faculty of Fisheries and Marine Sciences, the Faculty of Animal Husbandry and Agriculture, the Faculty of Science and Mathematics [for example, 16,17,18, . Most research related to the health sector is carried out by the Faculty of Medicine and the Faculty of Public Health. Meanwhile, research on the nonphysical environment and social humanities is carried out by other faculties. Research 
related to this environment is not only carried out on campus, but also in the environment and community outside the campus. Based on this, the accumulated amount of funds for research related to environment and sustainability is very large and dominates compared to funds for other research.

Most of the environmental studies, both physical and non-physical and social humanities, are related to the 17 goals in the SDGs. Undip's support for the achievement of the SDGs is very real [19], not only in the form of the establishment of the SDGs Center, but also in other programs. For example, all study programs must have courses related to SDGs, so that the number of courses in all study programs at Undip is very large. In the last two years, the theme of the Student Community Fieldwork (KKN) of Undip is SDGs, so that the understanding of SDGs for students has increased significantly, as well as spreading this understanding to the community where the fieldwork is carried out. Since 2017 Undip has prepared Sustainability reports (English version) and SDGs Activity Reports (Indonesian version) which are open and can be downloaded via sustainability.undip.ac.id. In the SDGs activity report, various activities carried out related to the 17 goals are provided, and links related to media coverage are also provided.

\section{Research Challenges}

Although research activities at Undip have improved very well, which is reflected in the result of publications and patents, there are some challenges ahead that need to be overcome. First is the low citation of publications produced by Undip academics. There are two possibilities, namely that many publications through seminar proceedings or publication in international journals are not good enough. For that, we need special strategies and programs to increase citation [20,21]. Undip encourages research publications to good journals (for example Q1 or Q2) and reduces publication in proceedings or unindexed journals, including avoiding publication in predatory journals. Second, there are difficulties in producing patent results. Besides requiring several advanced stages to reach the level of commercialization, it is also a challenge to convince the industry to produce products based on patents from Undip. Some specific strategies are needed to increase the commercialization of research results from universities $[22,23]$. For this reason, Undip has held business meetings with industry, by conducting research collaborations with industry, or by having Technology Transfer Office (TTO).

\section{Summary}

Improvement of research capacity at Universitas Diponegoro was done by several policies i.e. increasing the capacity of human resources; improvement of main and supporting facilities; increasing the availability of research funding; collaboration; and creating a conducive environment to research development at universities. However, there are two challenges which need to be addressed i.e. the need to increase the citation rate of publications and commercialization of patents.

\section{References}

1. Setyawan, F.B., Listiara, A., 2018. Hubungan Antara Persepsi Mengenai Status Perguruan Tinggi Negeri Badan Hukum Dengan Kesiapan Untuk Berubah Pada Tenaga Kependidikan Universitas Diponegoro. Empati, 6(4), pp.6-10.

2. Yuliawati, S., 2012. Kajian Implementasi Tri Dharma Perguruan Tinggi sebagai Fenomena Pendidikan Tinggi di Indonesia. Jurnal IImiah Widya, p.218712. 
3. Sudirwo, D., 2002. Otonomi Perguruan Tinggi Hubunganya dengan Otonomi Daerah. Manajerial: Jurnal Manajemen dan Sistem Informasi, 1(1), pp.72-79.

4. Ambariyanto, A., Utama, Y.J., Budihardjo, M.A., Purwanto, P., 2018. Undip Initiative for Sustainability (UNITY): A University Sustainability Program. In E3S Web of Conferences (Vol. 73, p. 02003). EDP Sciences.

5. Ambariyanto, A., Utama, Y.J., Darsono, D., Setyiono, B., Zainuri, M., Noor, R., 2017. Supporting Indonesian government maritime policy, through diponegoro university main scientific interest. Advanced Science Letters, 23(10), pp.10061-10063.

6. Delery, J.E., 1998. Issues of fit in strategic human resource management: Implications for research. Human resource management review, 8(3), pp.289-309.

7. Miracle, V.A., 2007. Thinking about certification. Dimensions of Critical Care Nursing, 26(2), pp.72-75.

8. Haley, R., 2009. A framework for managing core facilities within the research enterprise. Journal of biomolecular techniques: JBT, 20(4), p.226.

9. Geuna, A., Martin, B.R., 2003. University research evaluation and funding: An international comparison. Minerva, 41(4), pp.277-304.

10. Abdillah, R., 2017. Implementasi fuzzy simple additive weighting (SAW) sebagai pendukung keputusan pada beasiswa penelitian. STRING (Satuan Tulisan Riset dan Inovasi Teknologi), 2(1), pp.74-83.

11. Gulbrandsen, M., Smeby, J.C., 2005. Industry funding and university professors' research performance. Research policy, 34(6), pp.932-950.

12. Yoshikane, F., Nozawa, T., Shibui, S., Suzuki, T., 2009. An analysis of the connection between researchers' productivity and their co-authors' past attributions, including the importance in collaboration networks. Scientometrics, 79(2), pp.435-449.

13. Melin, G., 2000. Pragmatism and self-organization: Research collaboration on the individual level. Research policy, 29(1), pp.31-40.

14. Lee, Y.S., 2000. The sustainability of university-industry research collaboration: An empirical assessment. The journal of Technology transfer, 25(2), pp.111-133.

15. Ahn, M.J., Meeks, M., 2008. Building a conducive environment for life science-based entrepreneurship and industry clusters. Journal of commercial biotechnology, 14(1), pp.20-30.

16. Hapsari, I.D., Sumarjiyanto, N., Purwanti, E.Y., 2014. Perencanaan dan Penganggaran Kampus Berkelanjutan: Green Campus Universitas Diponegoro. Teknik, 35(2), pp.8693.

17. Samadikun, B.P., 2004. Dampak Keberadaan Kampus Undip Tembalang Terhadap Kondisi Lingkungan Perumahan di Sekitarnya (Doctoral dissertation, PROGRAM PASCASARJANA UNIVERSITAS DIPONEGORO).

18. Utama, Y.J., Ambariyanto, A., Samudro, G., 2018. Current practices of waste management at Universitas Diponegoro campus, Indonesia. In E3S Web of Conferences Vol. 48, p. 04002. EDP Sciences.

19. Utama, Y.J., Ambariyanto, A., Zainuri, M., Darsono, D., Setyono, B. and Putro, S.P., 2018, May. Sustainable development goals as the basis of university management towards global competitiveness. Journal of Physics: Conference Series Vol. 1025, No. 1, p. 012094). IOP Publishing.

20. Shahbazi-Moghadam, M., Salehi, H., Ale Ebrahim, N., Mohammadjafari, M., Gholizadeh, H., 2015. Effective factors for increasing university publication and citation rate. Asian Social Science, 11(16), pp.338-348., 
21. Ale Ebrahim, N., Salehi, H., Embi, M.A., Habibi, F., Gholizadeh, H., Motahar, S.M., Ordi, A., 2013. Effective strategies for increasing citation frequency. International Educatio

22. Zhao, F., 2004. Commercialization of research: a case study of Australian universities. Higher Education Research \& Development, 23(2), pp.223-236.,

23. Yaakub, N.I., Hussain, W.M.H.W., Rahman, M.N.A., Zainol, Z.A., Mujani, W.K., Jamsari, E.A., Sulaiman, A. and Jusoff, K., 2011. Challenges for commercialization of university research for agricultural based invention. World Applied Sciences Journal, 12(2), pp.132-138. 